\title{
Review: Role of herbivores in sustainable agriculture in Sub-Saharan Africa
}

\author{
A. A. Ayantunde ${ }^{1 \dagger}$, A. J. Duncan ${ }^{2 a}$, M. T. van Wijk ${ }^{3}$ and P. Thorne ${ }^{2}$ \\ ${ }^{1}$ International Livestock Research Institute (ILRI), 01 BP 1496, Ouagadougou, Burkina Faso; ${ }^{2}$ International Livestock Research Institute (ILRI), PO Box 5689 Addis \\ Ababa, Ethiopia; ${ }^{3}$ International Livestock Research Institute (ILRI), PO Box 30709, 00100 Nairobi, Kenya
}

(Received 27 November 2017; Accepted 4 June 2018; First published online 24 August 2018)

The role of herbivorous livestock in supporting the sustainability of the farming systems in which they are found is complex and sometimes conflicting. In Sub-Saharan Africa (SSA), the integration of livestock into farming systems is important for sustainable agriculture as the recycling of nutrients for crop production through returns of animal manure is a central element of the dominant mixed crop-livestock systems. Sustainable agriculture has been widely advocated as the main practical pathway to address the challenge of meeting the food needs of the rapidly growing population in SSA while safeguarding the needs of future generations. The objective of this paper is to review the state of knowledge of the role of herbivores in sustainable intensification of key farming systems in SSA. The pathways to sustainable agriculture in SSA include intensification of production and livelihood diversification. Sustainable agricultural practices in SSA have focused on intensification practices which aim to increase the output: input ratio through increasing use of inputs, introduction of new inputs or use of existing inputs in a new way. Intensification of livestock production can occur through increased and improved fodder availability, genetic production gains, improved crop residue use and better nutrient recycling of manure. Livestock deliver many 'goods' in smallholder farming systems in SSA including improving food and nutrition security, increased recycling of organic matter and nutrients and the associated soil fertility amendments, adding value to crop residues by turning them into nutrient-rich foods, income generation and animal traction. Narratives on livestock 'bads' or negative environmental consequences have been largely shaped by the production conditions in the Global North but livestock production in SSA is a different story. In SSA, livestock are an integral component of mixed farming systems and they play key roles in supporting the livelihoods of much of the rural population. None-the-less, the environmental consequences of livestock production on the continent cannot be ignored. To enhance agricultural sustainability in SSA, the challenge is to optimize livestock's role in the farming systems by maximizing livestock 'goods' while minimizing the 'bads'. This can be through better integration of livestock into the farming systems, efficient nutrient management systems, and provision of necessary policy and institutional support.

Keywords: sustainable intensification, smallholder farming systems, ruminant livestock, food security, trade-off

\section{Implications}

This review shows that the role of livestock in agricultural sustainability in Sub-Saharan Africa (SSA) is complex and conflicting. In view of the marked diversity in biophysical and socio-economic contexts of smallholder crop-livestock farmers in SSA, the concept of sustainable agriculture has to be adapted to varied local values and constraints. Livestock deliver a range of 'goods' in the dominant smallholder mixed crop and livestock systems in Africa, therefore the overemphasis on the environment is simplistic and should be

\footnotetext{
a Present address: Global Academy of Agriculture and Food Security, The Royal (Dick) School of Veterinary Studies and The Roslin Institute, University of Edinburgh, Easter Bush Campus, Midlothian, EH25 9RG, UK.

${ }^{\dagger}$ E-mail: a.ayantunde@cgiar.org
}

moderated by the enormous importance of livestock in generating food security for some of the more vulnerable people in the world.

\section{Introduction}

The dominant herbivores in SSA farming systems are ruminants (cattle, sheep and goats). Cattle are considered critical for sustainable agriculture in Africa as the main source of manure and draught power for crop production. In addition to the importance of ruminants in nutrient cycling, they fulfil many socio-cultural functions in the livelihoods of smallholder farmers in SSA such as storage of wealth, source of dowry payment, particularly among the pastoral societies, and as a risk aversion strategy in mixed crop-livestock 
systems (Vall et al., 2017). Owning livestock is critical for household food security in many African countries. The livestock production systems of SSA are largely defined by pastoral systems dominant in the hyper-arid and arid zones, and mixed crop-livestock systems which dominate in the semi-arid and sub-humid zones (Table 1). Even within a specific livestock system however, livestock keepers are not homogenous as they differ in terms of livestock assets, socioeconomic endowment and cultural ties to livestock (Vall et al., 2017).

There is general consensus around the important role that herbivorous livestock play in the sustainability of the farming systems in which they are found, although there is some debate around the specifics of their positive and negative contributions. Ensuring that herbivores make a net positive contribution to sustainability requires livestock managers to carefully balance their positive and negative impacts. Integration of livestock into farming systems permits recycling of nutrients from crop residues into animal manure which acts as an essential nutrient source for crop production. This is a hallmark of mixed crop and livestock systems (Pretty et al., 2011; Rudel et al., 2016) and one that contributes significantly to overall system sustainability by reducing the need for external inputs. Livestock, and particularly ruminants, traditionally graze on natural pasture, forest areas, roadsides, fallow lands, crop re-growth or residues such as straws, legume haulms, and other by-products, thereby allowing more efficient use of land than if it were only cropped. For example, the keeping of livestock has been essential for survival in divergent systems such as those of the agro-pastoralists in SSA, and animals have long been essential for sustaining crop yields in the infieldoutfield systems of West and Eastern Africa, where dung and draught from wasteland grazing (outfields) is used for crop cultivation on the infields around the homesteads (e.g. Schiere et al., 2002; Giller et al., 2011).

The objective of this paper is to review the state of knowledge regarding the role of herbivores in the sustainable intensification of key farming systems in SSA. In this paper we will argue that the over-emphasis on the environmental consequences of livestock production is simplistic and should be moderated by the enormous importance of livestock in generating food security for some of the more vulnerable people in the world and other livestock 'goods' or benefits in smallholder farming systems in SSA.

\section{Sustainable agriculture: definition of concept and need}

The concept of sustainability is increasingly recognized as a desirable, if not essential, outcome in many areas of agricultural research. However, researchers often struggle to define it when challenged to do so. Indeed, Pretty et al. (2011) draw attention to more than 100 different ways of defining sustainability and it can be concluded from this pot pourri that there is no one definition to fit all possible scenarios. The umbrella definition of sustainable development, going back to 1978 , is perhaps that of the World Commission on Environment and Development (also known as the Brundtland Commission), namely 'development that meets the needs of the present without compromising the ability of future generations to meet their own needs'. Whilst there are many subtleties that are not captured by this definition, it does serve to emphasize the essential element of considering the implications of current practice for future generations as well as our own.

The concept of sustainable agriculture essentially follows the key principles inherent in sustainable development. Rudel et al. (2016) defined sustainable agriculture as producing enough food for consumers and enough income for farmers while maintaining agro-ecosystem services. National Research Council (NRC) (2010) in its publication 'Toward Sustainable Agricultural Systems in the 21st Century' defined sustainable agriculture as agriculture that satisfies human food, feed and fibre needs; enhances environmental quality and the resource base; sustains economic viability and enhances the quality of life for farmers, farm workers and society as a whole. From these various definitions, the common elements of sustainable agriculture include food production for both present and future needs, persistence of the systems (i.e. capacity to continue to produce desired outputs over long periods), resilience (ability to absorb shocks and stresses, and deliver the desired outputs) and environmental friendliness. (Schiere et al., 2002; Pretty et al., 2011). Nonetheless, the concept of agricultural sustainability inherently lacks specificity. Approaches to overcoming this difficulty usually centre around the definition of indicators and metrics (Smith et al., 2017) that the evidence suggests are likely to be reliably associated with ultimately sustainable outcomes.

In view of marked diversity in biophysical and socioeconomic contexts of smallholder crop-livestock farmers in

Table 1 Key livestock production systems in sub-Saharan Africa

\begin{tabular}{|c|c|c|c|c|c|}
\hline System & Agro-ecological zone & Rainfall (mm) & Length of growing period (day) & Dominant animal species & Dominant crop \\
\hline Pastoral & Hyper arid, arid & $<400$ & 0 to 75 & Cattle, sheep goat, camel & - \\
\hline Agro-pastoral & Arid, semi-arid & 400 to 600 & 75 to 90 & Cattle, sheep, goat & Sorghum, millet \\
\hline \multirow[t]{4}{*}{ Mixed crop-livestock } & Semi-arid & 500 to 800 & 90 to 180 & Cattle, sheep goat, pig, poultry & Maize, sorghum, millet \\
\hline & Sub-humid & 800 to 1500 & 180 to 270 & Cattle, sheep goat, pig, poultry & Roots/tubers, maize \\
\hline & Humid & $>1500$ & $>270$ & Sheep, Goat, Pig, poultry & Roots/tubers \\
\hline & $\begin{array}{l}\text { Highland } \\
\text { Semi-arid sub-humid }\end{array}$ & & $75-180$ & $\begin{array}{l}\text { Cattle, sheep, goat } \\
\text { Cattle, sheen }\end{array}$ & $\begin{array}{c}\text { Wheat, potato, teff } \\
\text { Maize }\end{array}$ \\
\hline
\end{tabular}

Adapted from Otte and Chilonda (2002). 
SSA, the concept of sustainable agriculture has to be adapted to varied local values and constraints. This implies that agricultural practices that can be regarded as sustainable in one region may not be sustainable in another. In this paper, we will adopt as a working definition of sustainable agriculture, 'agriculture that is sufficiently productive to meet food needs in both short and long-terms, and that is economically viable, environmentally friendly and socially acceptable' (Schiere et al., 2002; NRC, 2010).

\section{The role of livestock in sustainable agriculture in Sub-Saharan Africa}

In SSA, sustainable agricultural practices have focused on intensification practices which aim to increase the efficiency (output: input ratio) of production systems. Intensification of farming systems will depend on factors such as farmers' agro-ecological potential, economic conditions, market situation, policy environment, institutional capacity and available technological options (Gunton et al., 2016). Tactics for intensification include increasing use of inputs, introduction of new inputs to the system, and or use of existing inputs in a new way (Pretty et al., 2011) provided that these changes result in a disproportionate increase in associated outputs. Some common intensification practices in mixed crop and livestock systems include application of inorganic fertilizer, use of improved seed, conservation agriculture and small-scale mechanization alongside animal-related interventions such as animal traction, animal manure use, improved breeds and improved feeding practices (Table 2). Generally, capital-intensive intensification options are not widely adopted in SSA due to the obvious constraint of lack of financial resources (Vall et al., 2017).

Application of animal manure to cropped land is widely practiced in SSA and there is widespread evidence of beneficial effects on grain yield and soil fertility (Vall et al., 2017). Application of animal manure is normally pivotal in mixed crop-livestock systems. In African Drylands, often only manured crop fields are in positive nutrient balance as shown by results of a study of livestock-mediated nutrient transfers from south-western Niger (Hiernaux and Ayantunde, 2004; Table 3). The main constraints to manure application is always inadequate quantity due to low animal numbers and a shortage of labour for distributing the manure.

Associated with peri-urban dairy production in many African countries is the use of improved dairy cows (Anderson, 2003; Paul et al., 2018) which produce more milk than local breeds provided they are well fed. For example in Rwanda, the government provided crossbred cow to poor farmers under the 'one cow per poor family' programme which aims to improve food and nutrition security, and reducing poverty (Paul et al., 2018). The crossbred cows produced 2 to $4 \mathrm{l} /$ cow per day compared with $2 \mathrm{l} /$ cow per day for the local breed (Paul et al., 2018). Although crossbreds make a big difference to yield potential, there are relatively few examples of economically sustainable practices that allow that potential to be realised. The main constraint to more widespread use of improved livestock breeds is lack of artificial insemination, high feed requirements of the improved breeds, reduced disease resistance and lack of necessary animal husbandry skills.

Use of animals (bull, oxen, horse and donkey) for traction is also a common practice in mixed crop and livestock systems in SSA (Savadogo et al., 1998; Sheahan and Barrett, 2017). Animal traction is widely practiced to plough crop field and for weeding in many farming systems in SSA, particularly for cash crops such as cotton in West African Sahel. Lack of bulls, particularly in West Africa, and high feed requirements are often the constraints to use of animal traction in mixed crop and livestock systems.

Food security is an urgent and immediate challenge in SSA due to a rapidly growing population coupled with lagging agricultural growth (The Montpellier Panel, 2013). Addressing this challenge requires sustainable agricultural practices and choices to significantly increase yields on existing agricultural land. Livestock have an important role to play in enhancing food security and particularly nutritional security. Although there is increasing consumption of animal source food in the human diet in many countries in SSA (such as Burkina Faso, Ghana, Ethiopia, Kenya; Food and Agriculture Organization of the United Nations (FAO), 2011), the diet is still largely dominated by the intake of basic cereal-based staple foods which are usually deficient in protein and micro-nutrients necessary for healthy human development (Reynolds et al., 2015). The consumption of animal products is closely related to per capita income with the urban population consuming higher amounts of animal protein due to their growing financial means. Consumption of animal protein is particularly important for children under 5 years and women of reproductive age. The importance of consumption of animal source food for cognitive development of children is well documented (Fan and Brzeska, 2016). For example, a nutritional study in Gourma in the Northern part of Mali showed that the children of mobile pastoralists were better nourished based on weightheight, weight-age and height-age measures than children of sedentary farmers (Pederson and Benjaminsen, 2008). This difference was largely attributed to consumption of milk and milk products by the pastoralist children underscoring the important role that livestock play in human nutrition. Households that keep livestock are more likely to consume animal-source food because of their proximity to these nutrient-rich foods (Reynolds et al., 2015). Increased consumption of animal-source food by rural households reduces stunting in children and improves the health of household members, particularly children and vulnerable women (Pedersen and Benjaminsen, 2008). One pathway to improve the consumption of animal protein is through improvements in livestock production. Agricultural production practices that lead to increased grain and livestock productivity will likely impact positively on food security as observed by the respondents in a survey in two provinces in Burkina Faso regarding the impact of intensification practices on household food security (Figure 1). 
Ayantunde, Duncan, van Wijk and Thorne

Table 2 Benefits and constraints of some intensification practices in smallholder mixed crop-livestock systems in sub-Saharan Africa

\begin{tabular}{|c|c|c|c|c|}
\hline Practice & Benefit & Constraints & Extent of adoption & Reference \\
\hline Fertilizer application & $\begin{array}{l}\text { Improve soil nutrient } \\
\text { Increase crop } \\
\text { productivity }\end{array}$ & $\begin{array}{l}\text { Unaffordable to many } \\
\text { smallholder farmers } \\
\text { Difficult for rural farmers to } \\
\text { access } \\
\text { Ineffective in absence of } \\
\text { sufficient organic matter }\end{array}$ & Widely used but at low rates & $\begin{array}{l}\text { Pretty et al. (2011); } \\
\text { Sheahan and } \\
\text { Barrett (2017) }\end{array}$ \\
\hline $\begin{array}{l}\text { Application of animal } \\
\text { manure }\end{array}$ & $\begin{array}{l}\text { Improve soil nutrients, } \\
\text { soil organic matter } \\
\text { Improve water } \\
\text { infiltration capacity } \\
\text { Improve nutrient } \\
\text { cycling in the system } \\
\text { Increased grain yield }\end{array}$ & $\begin{array}{l}\text { Inadequate quantity due to low } \\
\text { number of animals } \\
\text { Lack of means of transport } \\
\text { Labour to apply the manure } \\
\text { Stealing of corralled animals } \\
\text { Other competitive use of } \\
\text { manure } \\
\text { GHG emission }\end{array}$ & $\begin{array}{l}\text { Widely practiced but at low rate due } \\
\text { to inadequate quantity }\end{array}$ & $\begin{array}{l}\text { NRC (2010); Vall et al. } \\
\quad(2017)\end{array}$ \\
\hline $\begin{array}{l}\text { Use of improved crop } \\
\text { varieties }\end{array}$ & $\begin{array}{l}\text { Higher grain yield } \\
\text { Higher fodder } \\
\text { biomass for livestock } \\
\text { Climate smart }\end{array}$ & $\begin{array}{l}\text { High cost } \\
\text { Low availability due to weak } \\
\text { seed systems } \\
\text { May not be locally preferred }\end{array}$ & $\begin{array}{l}\text { Generally low except for improved } \\
\text { dual purpose leguminous crops } \\
\text { such as cowpea }\end{array}$ & $\begin{array}{l}\text { Pretty et al. (2011); } \\
\text { Sheahan and } \\
\text { Barrett (2017) }\end{array}$ \\
\hline $\begin{array}{l}\text { Water conservation } \\
\text { techniques (zai, stone } \\
\text { row, half-moon, etc.) }\end{array}$ & $\begin{array}{l}\text { Reduce runoff, collect } \\
\text { water and nutrients } \\
\text { Reduces erosion } \\
\text { Rehabilitation of } \\
\text { degraded land }\end{array}$ & High labour demand & Highly localized in the dryland areas & $\begin{array}{l}\text { Rockström et al. } \\
\text { (2002); } \\
\text { Douxchamps et al. } \\
\text { (2014) }\end{array}$ \\
\hline Conservation agriculture & $\begin{array}{l}\text { Increase grain yield } \\
\text { Maximize nutrient } \\
\text { retention in the } \\
\text { system } \\
\text { Reduce water runoff } \\
\text { and water-caused } \\
\text { erosion }\end{array}$ & $\begin{array}{l}\text { Competitive use of crop residues } \\
\text { as animal feed } \\
\text { Weed and pest control }\end{array}$ & Generally low adoption & $\begin{array}{l}\text { Baudron et al., (2014); } \\
\quad \text { Rudel et al. (2016) }\end{array}$ \\
\hline Improved livestock breeds & $\begin{array}{l}\text { Higher productivity } \\
\text { Efficient nutrient use } \\
\text { Reduce GHG } \\
\text { emission per unit of } \\
\text { production }\end{array}$ & $\begin{array}{l}\text { Lack of artificial insemination } \\
\text { Availability of improved breed } \\
\text { well adapted to the } \\
\text { environment } \\
\text { High feed requirements } \\
\text { Multiple production objectives } \\
\text { Disease risk }\end{array}$ & $\begin{array}{l}\text { Generally low adoption except in } \\
\text { peri-urban dairy production } \\
\text { systems }\end{array}$ & $\begin{array}{l}\text { Anderson (2003); } \\
\text { Pretty et al. (2011) }\end{array}$ \\
\hline Fodder production & $\begin{array}{l}\text { High biomass } \\
\text { production } \\
\text { High nutritional value } \\
\text { Improved animal } \\
\text { production }\end{array}$ & $\begin{array}{l}\text { Availability of seed or seedling } \\
\text { Lack of technical capacity } \\
\text { Economic viability }\end{array}$ & $\begin{array}{l}\text { Generally low except in peri-urban } \\
\text { dairy production systems }\end{array}$ & $\begin{array}{l}\text { Pretty et al. (2011); } \\
\quad \text { Herrero et al. (2013) }\end{array}$ \\
\hline Composting & $\begin{array}{l}\text { Increase soil carbon and } \\
\text { soil organic matter } \\
\text { Increase nutrient } \\
\text { availability } \\
\text { Increase crop yield } \\
\text { Improve soil moisture } \\
\text { retention and water } \\
\text { infiltration }\end{array}$ & $\begin{array}{l}\text { High labour demand } \\
\text { Difficulty in transport } \\
\text { Can lead to significant loss of } \\
\text { ammonia, } \mathrm{CH}_{4} \text { and } \mathrm{N}_{2} \mathrm{O} \text { to the } \\
\text { atmosphere }\end{array}$ & Widely adopted in dryland areas & $\begin{array}{l}\text { Kabore et al. (2010); } \\
\text { NRC (2010) }\end{array}$ \\
\hline Small scale mechanization & $\begin{array}{l}\text { Increased productivity } \\
\text { Reduced drudgery }\end{array}$ & High cost of farm machinery & $\begin{array}{l}\text { Widely adopted at low level due to } \\
\text { high cost }\end{array}$ & $\begin{array}{l}\text { Diao et al. (2014); } \\
\text { Sheahan and } \\
\text { Barrett (2017) }\end{array}$ \\
\hline Animal traction & $\begin{array}{l}\text { Increased productivity } \\
\text { Reduced drudgery }\end{array}$ & $\begin{array}{l}\text { Lack of bull/oxen } \\
\text { Feed requirements of bull/ } \\
\text { oxen }\end{array}$ & $\begin{array}{l}\text { Widely practiced but often limited } \\
\text { to cash crops such as cotton }\end{array}$ & $\begin{array}{l}\text { Savadogo et al. } \\
\text { (1998); Sheahan } \\
\text { and Barrett (2017) }\end{array}$ \\
\hline
\end{tabular}


Role of herbivores in sustainable agriculture

Table 3 Dry matter, nitrogen and phosphorus balance of different land use types in Fakara, south-western Niger in 1998

\begin{tabular}{lcccc}
\hline \hline Land use type & \% area of village land & Dry matter (kg/ha per year) & Nitrogen (kg/ha per year) & Phosphorus (kg/ha per year) \\
\hline Rangeland & 13.2 & -135 & -3.7 & -0.23 \\
Fallow & 25.0 & -112 & -2.9 & -0.10 \\
Unmanured crop field & 53.9 & -126 & -2.4 & -0.13 \\
Manured crop field & 7.9 & 400 & 7.7 & 1.09 \\
\hline \hline
\end{tabular}

Adapted from Hiernaux and Ayantunde (2004). Only manured field had a positive nutrient balance but only $10 \%$ of the crop field in the study site is manured.

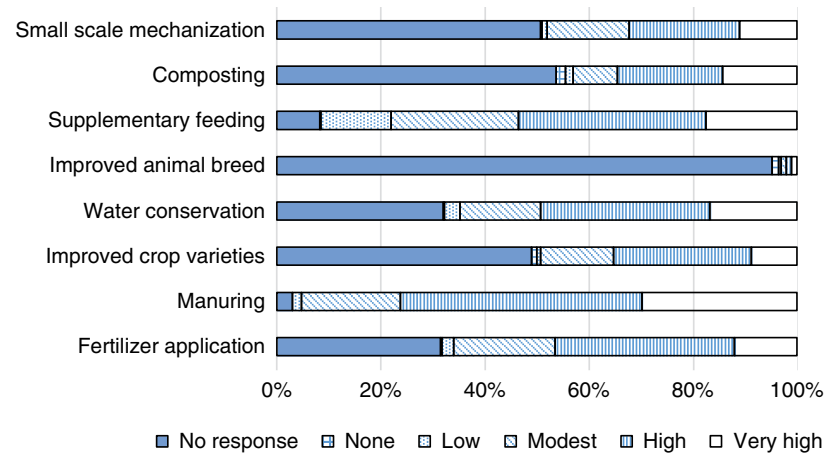

Figure 1 Perceived impact of intensification practices on household food security in Burkina Faso $(n=400$ households interviewed in Seno and Yatenga provinces).

Household survey data show that another key food security role of livestock is in generating income, so that food can be bought throughout the year. Families that keep few livestock are the most vulnerable to food shortages based on evidence from surveys in mixed crop-livestock systems in four countries in West Africa (Figure 2). In Figure 3 (after Ritzema et al., 2017), at contrasting sites in Burkina Faso, Ethiopia and Kenya, the relative importance of on- and offfarm activities for food security is quantified, illustrating that both consumption and sales of livestock products are essential for food security. In the agro-pastoral region in Borana, southern Ethiopia, direct consumption of livestock products plays a dominant role in livelihoods, while in the other sites, sales of livestock products are important for cash generation. These results also show that the most food secure households are also typically the households with most livestock and therefore the highest importance of livestock products in their livelihood compared with the other food security groups.

\section{Drivers of sustainable agriculture in Sub-Saharan Africa and some constraints}

Population growth, climate change and natural resource availability (land and water) are the main drivers of sustainable intensification in SSA (Pretty et al., 2011). There is a need to produce more food on less land to meet the growing food demand of the population, but this must be done in a way that does not undermine environmental integrity. The average annual population growth rate of $2.7 \%$ in SSA has led to the

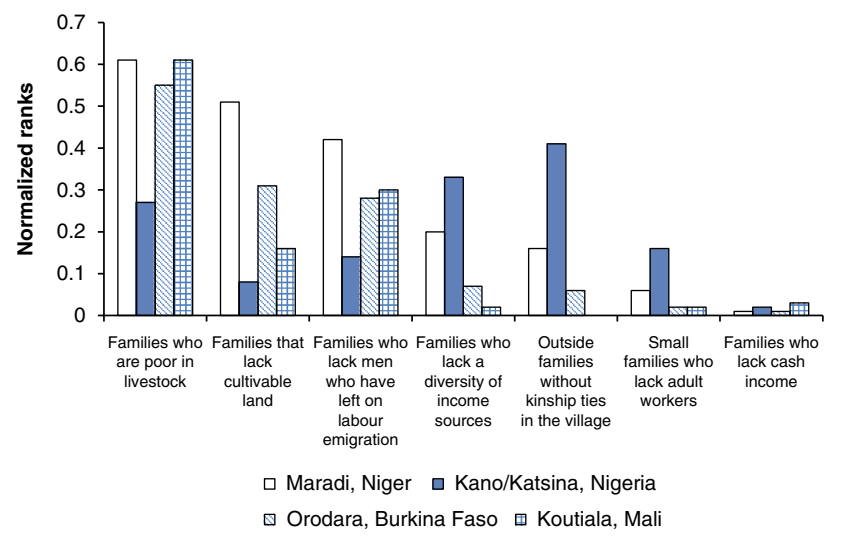

Figure 2 Vulnerability of different families to food shortage (normalized ranks 0 to 1 ) in West Africa (data from survey of 550 households in Burkina Faso, Mali, Niger and Nigeria). Poor in livestock means those with no cattle and less than 5 sheep and goat. Those that lack cultivable land are those who lack access to land often immigrants.

challenge of feeding more people which necessitates an increase in agricultural production (The Montpellier Panel, 2013).

Climate change and variability has compelled farmers to diversify species composition of their herds (Zougmoré et al., 2016; Vall et al., 2017). For example, repeated occurrence of droughts in the Sahel has led many pastoralists, who were once solely dependent on livestock for their livelihoods, to adopt agro-pastoralism (i.e. rearing livestock and growing crops; Zougmoré et al., 2016). In response to climate change, many crop farmers have also diversified in the past two decades into rearing livestock due to repeated crop failure associated with droughts (Zougmoré et al., 2016). Investment in irrigation has been advocated as a potential 'game changer' in improving agricultural productivity in view of the present very low irrigated area (4\% of the cultivated land) in Africa (The Montpellier Panel, 2013).

Some barriers to sustainable intensification in SSA include lack of policy support to smallholder farmers (Garnett et al., 2013), a dysfunctional institutional environment (Hounkonnou et al., 2012), market failures, lack of appropriate productivity-enhancing agricultural technologies and low adoption where they are available, lack of access to credit, low use of external inputs and poverty leading to shorttermism among farmers. The policy (local, national and regional) and institutional environment (customary and modern) are key to sustainable agriculture in SSA. At continent level, the policy initiative of the African Governments 
Ayantunde, Duncan, van Wijk and Thorne
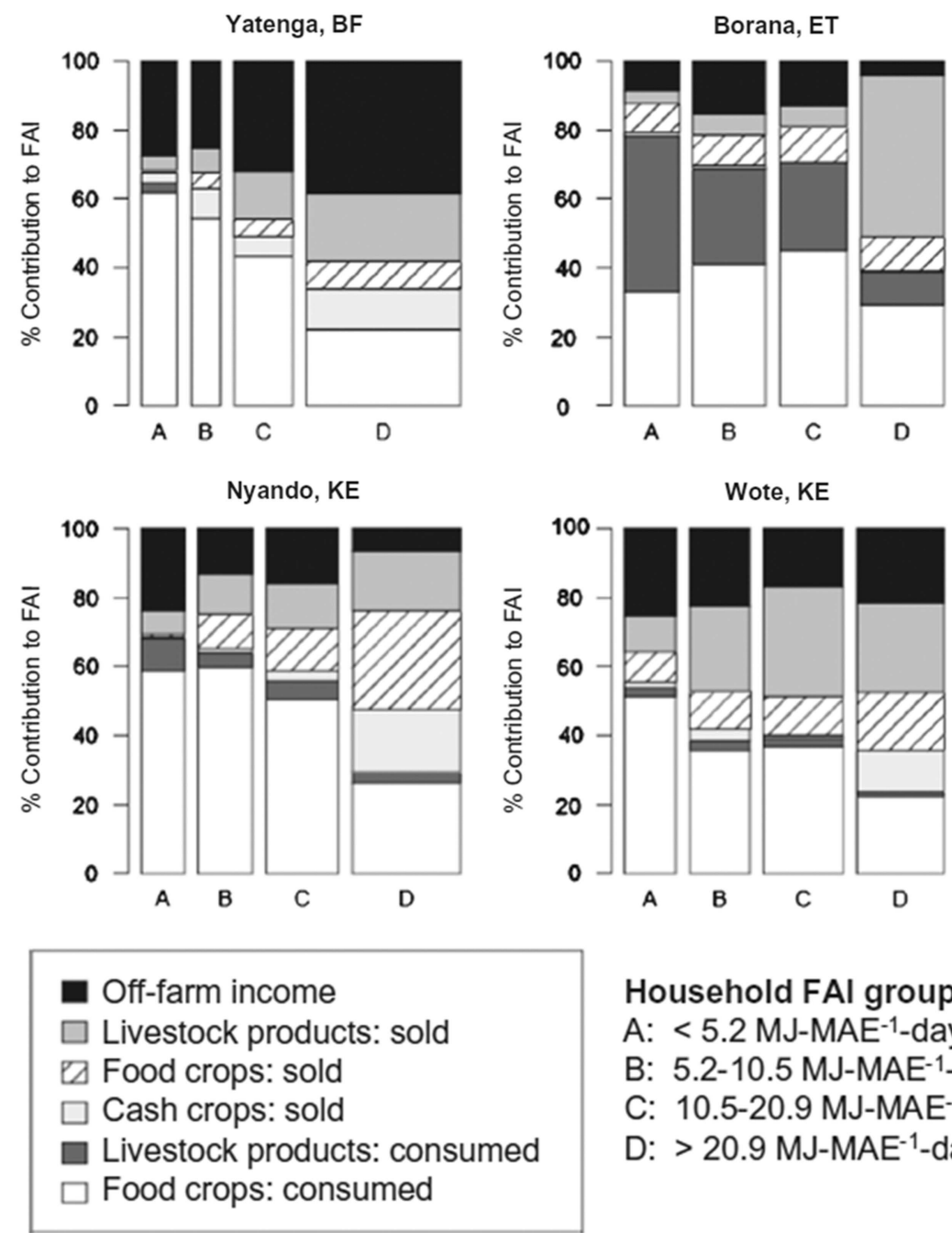
Household FAl groupings
A: $<5.2{\mathrm{MJ}-\mathrm{MAE}^{-1}-\text { day }^{-1}}^{-1}$

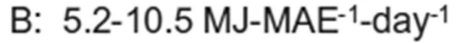
C: $10.5-20.9 \mathrm{MJ}^{-M^{-1} E^{-1}}$ day-1 $^{-1}$
D: $>20.9{\mathrm{MJ}-\mathrm{MAE}^{-1} \text {-day }}^{-1}$

Figure 3 Relative contribution of six livelihood sources to food security. Results reported by household food security groupings and by site, Yatenga, Burkina Faso (BF); Borana, Ethiopia (ET); Nyando and Wote, Kenya (KE). Column widths denote the relative household membership within each food security category at each site (after Ritzema et al., 2017). FAl is Food Availability Index while Household FAl groupings are expressed in MJ/male adult equivalent (MAE)/day.

to increase agricultural productivity known as the Comprehensive Africa Agriculture Development Programme has set a target of six per cent annual agricultural productivity growth rate. To achieve this target it has been recommended that $10 \%$ of the annual budget of each country should be spent on the agriculture sector at the Maputo Declaration (New Partnership for Africa's Development, 2003). This increased policy attention to agricultural growth is a welcome spur to agricultural intensification in Africa although the implementation may be lagging behind. Institutional issues that can impact on agricultural sustainability in SSA include natural resource governance, knowledge institutions (agricultural research and local institutions) and stakeholders' organizations, particularly farmers' networks/associations. Other factors such as insecurity and civil war, insecure land tenure and water rights, weak agricultural extension systems, and underfunding of national agricultural research systems further aggravate the difficulties facing agricultural production in SSA (Douxchamps et al., 2014).
Market development and the associated growing demand for agricultural products (food, e.g. grains, meat and milk; and processed food products) is another important factor determining agricultural sustainability (Garnett et al., 2013). This entails both more food and value addition. The barrier to sustainable agriculture of low use of external inputs could be attributed to extensive farming systems and the associated subsistence orientation of crop and livestock farmers. Besides, low use of external inputs could be due to poor financial resources among farmers, lack of access to external inputs and the high price of the inputs where available confounded by high production risk, as agriculture is largely rainfed in SSA, and high market risk. One opportunity to reduce the latter risk is the rapidly increasing availability of mobile phone technology. Increased use of mobile phones has facilitated real-time access to market information particularly prices of agricultural products (grains and live animals) which is influencing the decision of many rural farmers on when and where to sell their produce (Sheahan and Barrett, 2017). 


\section{Livestock-related intensification practices in Sub- Saharan Africa: pathways to sustainable agriculture}

Intensification of agricultural production has been widely advocated as the key pathway to sustainable agriculture in Africa. There is great potential for intensification of crop and livestock production in view of the current low productivity and high productivity gap (Gunton et al., 2016). For intensification to be sustainable, Pretty et al. (2011) suggested a number of criteria including efficient and prudent use of inputs, minimizing greenhouse gas (GHG) emissions or environmental costs, increasing the flow of environmental services and strengthening resilience. A well-known conceptual example of livestock intensification is the so-called livestock ladder (Udo et al., 2011), which describes a theoretical system that poor smallholders can use to step up from keeping small-stock to acquiring larger animals. Continued re-investment in the agricultural system is needed in the lowest parts of ladder, plus the availability of fodder to feed the growing stock. According to these authors, the economic benefits derived from livestock intensification depends on the rung of the ladder where the farmers are located. Thus, the smallest economic benefits will come from village poultry, followed by small ruminants, pigs and local cattle while the largest economic benefit will come from dairy cattle.

The livestock ladder gives a conceptual model of change in livestock holdings over time, but in practice the resourceconstrained smallholder crop and livestock farmers in SSA can directly potentially increase their livestock production (produce more per given land area and per unit livestock) through adoption of appropriate technological, social and institutional innovations, and through improvement of farmers' knowledge and capacity, and better market access (Pretty et al., 2011). For example, Amole et al. (2017) have shown through a simulation model of West Africa Dwarf goats production that with improved feeding management such as grazing with supplementation or cut-and-carry feeding systems, the pre-weaning growth rate of kids can be doubled and the pre-weaning mortality can be reduced from about $26 \%$ in the traditional free-range feeding system to between $5 \%$ and $12 \%$ in improved feeding systems. Similar results of increased animal productivity have been reported with improved feeding systems in smallholder dairy production in East Africa (Bebe et al., 2002). In Ethiopia, yield gap analyses of attainable milk yield by cows showed that replacing indigenous zebu with crossbred cattle could lead to doubling of milk yields, even on traditional diets, and to a profitable smallholder dairy enterprise (Mayberry et al., 2017). This demonstrates that there is great potential for livestock productivity and economic gains through more intensive livestock production.

The growing demand for livestock products particularly in urban areas also provides opportunity for the intensification of livestock production. Consumption of livestock products has been increasing over the years in all regions in SSA and these trends are expected to continue in the foreseeable future. For example, in West Africa, the current annual growth rates in livestock commodity consumption $(2.7 \%$ for mutton, $4 \%$ for poultry, $2.9 \%$ for milk and 3.3\% for beef; FAO, 2011) are much higher than for cereals (about 2\%). The growing demand for consumption of animal source food has been driven partly by rapidly growing cities, potentially opening up avenues to bridge nutritional gaps, as well as providing incomes and livelihoods for the population, including for target groups such as the poor, women and youth. In addition, the growing demand has also been driven by the improved regional economic performance in the last few decades, moving from the negative GDP growth rates observed in the early 1980s to annual growth rates that have remained positive since then. Though there will be continued growth in per-capita demand for livestock products in West Africa and other regions in Africa from 2000 to 2030, the absolute increase in annual per-capita consumption (in $\mathrm{kg} /$ person) during this period is still low compared with regions in Asia (FAO, 2011).

Another opportunity for sustainable agriculture in SSA is the increasing integration of crop and livestock production, though the level of integration may vary depending on the agro-ecological potential, socio-economic endowment, production objectives, natural resource base and local institutions. Better integration of crop and livestock production could improve the efficiency of nutrient cycling in farming systems and whole farm productivity (NRC, 2010; Vall et al., 2017). Integration of crop and livestock production provides opportunity for value addition to crop residues by the livestock through conversion of 'waste' products which cannot be consumed by humans (crop residues) into nutrient-rich foods. The contribution of crop residues to livestock diets will continue to increase in African farming systems depending on the agro-ecological zone in view of the declining grazing areas due to expansion of arable production, particularly in Africa drylands (Dongmo et al., 2012) For example, results from evaluation of feed resources in three countries in West Africa showed the increasing contribution of crop residues to livestock diets as we move from sub-humid zone $(<10 \%)$ to semi-arid zone (about 50\%; Figure 4). Similar trends are seen in a recent study in Ethiopia which assessed historical changes in feed sourcing across the pastoral to highland gradient and pointed to increasing importance of crop residues in livestock diets (Figure 5).

Better manure management also provides the opportunity to reduce GHG emissions in addition to contributing to efficient nutrient cycling in the mixed crop and livestock systems. Practices such as mulching or using cereal straws as beddings where animals are corralled have resulted in better capture of faecal and urinary nitrogen thereby reducing ammonia volatilization, which can be up $60 \%$ of excreted faeces and urine (Hiernaux and Ayantunde, 2004). Besides, the association of mulching and corralling of ruminants improves soil chemical properties which can lead to increase in grain yield and crop residue biomass.

In addition to intensification, livelihood diversification is an important pathway to sustainable agriculture in Africa. This can be defined as the process by which rural families construct a diverse portfolio of activities and social support 
Ayantunde, Duncan, van Wijk and Thorne

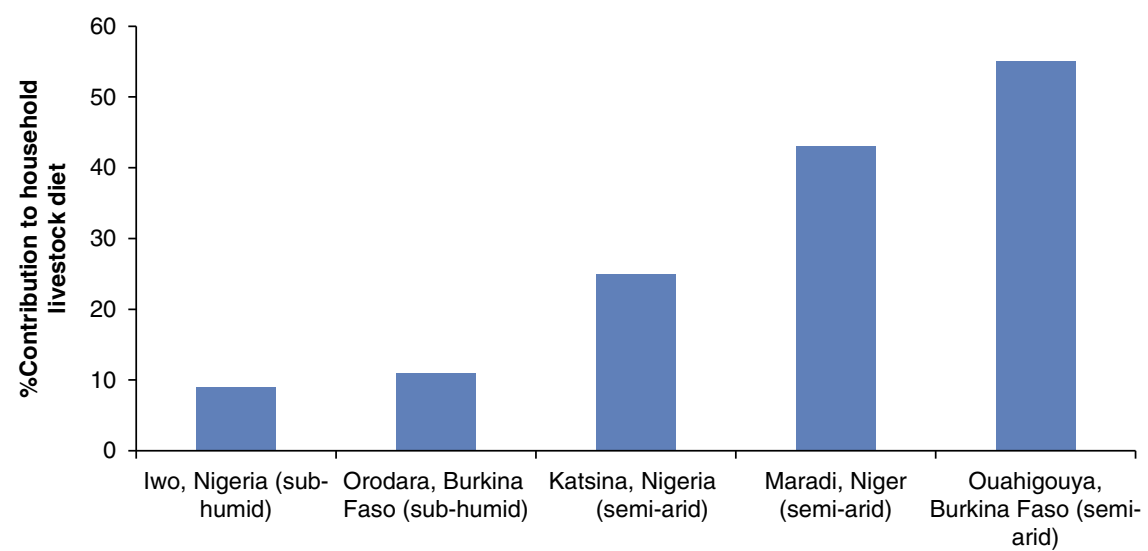

Figure 4 Contribution of crop residues to household livestock (cattle, sheep and goat) diet across agro-ecological zones in West Africa.

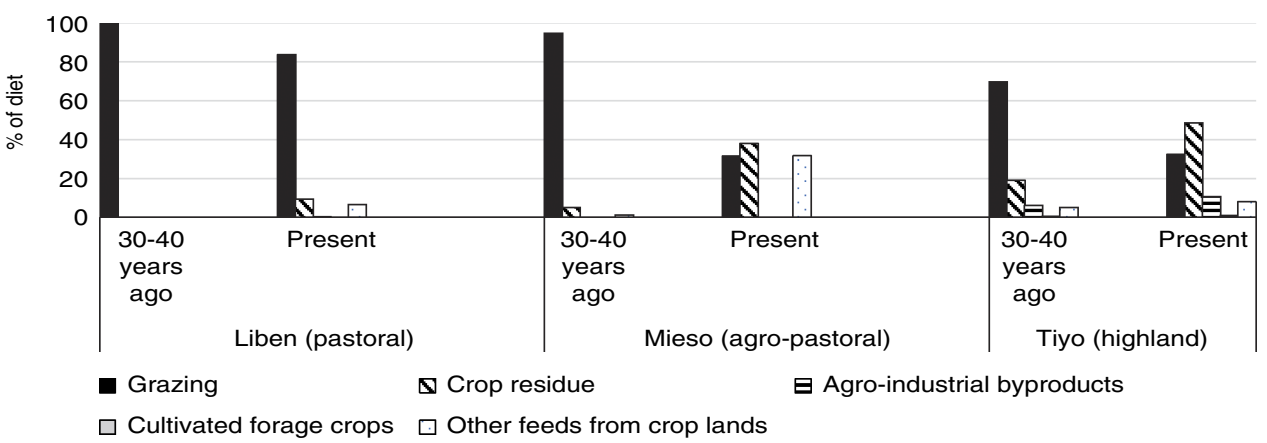

Figure 5 Historical changes in feed sourcing across the pastoral to highland gradient in Ethiopia, 30-40 years ago compared with present (2011) (adapted from Mekasha et al., 2014).

capabilities in order to survive and to improve their standards of living (Ellis, 1998). According to Ellis, diversification may occur both as a deliberate strategy by the household or be triggered by crises such as climatic shocks. Diversification may concern on-farm or off-farm activities. Off-farm activities such as small commerce, seasonal migration, etc., provide additional sources of revenue for rural households which may be invested in agricultural production. Livestock play an important role in diversification strategies, because of their diverse role in smallholder livelihoods: livestock produce food that can be directly consumed, while livestock products are also sold to generate essential cash for expenses. The livestock herd can also function as a flexible reserve for the farm household. For example, the repeated occurrence of droughts in the West African Sahel has led to significant shifts in herd composition from cattle to small ruminants (Zougmoré et al., 2016). Diversification of agricultural production systems is often associated with increased resilience of livelihoods and livestock can play a key role in the ability of smallholder households to deal with shocks (e.g. the 'banking' function of livestock in case of severe droughts) when major food crops fail. Both intensification and livelihood diversification pathways to sustainable agriculture are complementary. For example, money from seasonal migration by members of the agro-pastoral households is often invested in acquiring livestock and inputs for crop farming.

\section{Environmental consequences of livestock in sustainable agriculture}

In the previous sections we have stressed the 'goods' of livestock for sustainable intensification and increased recycling of organic matter and nutrients: soil fertility amendment through concentration of organic matter (either through grazing of crop residues or common grasslands), including enhanced nutrient cycling; the essential role of livestock in supplying traction and thereby the timely planting of crops at the start of the growing season; and adding value to crop residues leading to increased system productivity. In this section we will concentrate on the environmental consequences of livestock in sustainable agriculture in SSA.

Livestock have received much negative publicity in recent years for their impact on the environment (Steinfeld et al., 2006) and their role in disease transmission (Jones et al., 2008). Much of this negative messaging is influenced by livestock production practices and food consumption patterns in the Global North. Industrial production practices have serious environmental externalities including GHG emissions and pollution of air and water. Much of the feed used in such systems could be more efficiently used if directly consumed by humans (Wilkinson, 2011). Furthermore, levels of animal source food consumption in the Global North are much higher than in the Global South and this brings a range of health issues. Livestock production in SSA is a different 
story. In SSA, livestock are an integral component of mixed system agriculture as indicated above. They play key roles in the livelihoods of much of the rural population. None-theless environmental consequences of livestock production on the continent cannot be ignored.

\section{Greenhouse gas emissions}

Livestock are major contributors to GHG emissions globally. The publication from FAO on global assessment of emissions highlighted the considerable GHG impact of livestock estimating that $14 \%$ of global GHG emissions arise from the livestock sector (Gerber et al., 2013). This includes emissions associated with feed production including from land use change such as conversion of forests to grazing lands, animal production (enteric emissions and emissions from manure) and transport of feed. Livestock are increasingly viewed as a global bad with a strong lobby actively promoting reduced per capita consumption of animal source foods in the developed world. In terms of regional contributions to livestock-based GHG emissions, SSA does emerge as a hotspot. Recent work indicates that $75 \%$ of non- $\mathrm{CO}_{2}$ emissions are generated in the developing world with SSA responsible for a considerable share (Herrero et al., 2013). Expressing the numbers as emission intensities (emissions per unit of livestock product) presents an even starker picture with SSA emerging as a region with particularly high emission intensities. The high emission intensities in SSA are due largely to low feed use efficiency with large numbers of livestock subsisting on low levels of feeding and producing very low yields of milk and meat. Expressing GHG emissions per unit of livestock products ignores the wider contribution of livestock to livelihoods in the developing world. In SSA, cattle are kept for milk and meat but also for a range of other farm functions including traction, financial security and production of organic fertilizer among other uses (Hiernaux and Ayantunde, 2004). The narrow focus on emission intensities has been pointed out in recent work where the denominator in the intensity equation was broadened to include a range of livestock functions. Although based on a small case study in Kenya, this work showed the much lower emission intensities that emerge from a broader view of the contribution of livestock to farm livelihoods in the developing world and point the way for more balanced assessments in future (Weiler et al., 2014).

\section{Negative effects of grazing}

Further negative effects of livestock are related to loss of biodiversity through overgrazing and the associated environmental negative feedbacks (erosion, deforestation, introduction of invasive species, etc.) (Asner et al., 2004). This partly relates to increased human population pressure leading to encroachment of cropping into previous grazing areas. This reduces availability of rangelands as traditional grazing reserves and concentrates grazing on smaller areas with associated negative effects on rangeland condition and biodiversity. Expansion of cropping into previous grazing reserves may also have implications for release of the carbon currently locked up in pastures. Increased grazing intensity alters competition between grass and browse species and can lead to encroachment of grazing areas by shrubs and trees (D'Odorico et al., 2012) which provide less nutrition for domestic livestock (except perhaps goats). Furthermore, invasive shrubs can radically alter species composition of grazing areas with negative effects on rangeland quality. Domestic livestock can exacerbate the spread of invasive species through transfer of seed and by altering competitive relationships with native species. A further potentially negative effect of grazing is the transfer of nutrients from extensive grazing areas by removal of biomass through grazing. In general, nutrients removed through grazing are returned through excreta but where grazing livestock are corralled overnight the cycle can be broken. Increased erosion can also be attributed to excessive livestock grazing pressure. Soil loss can occur where heavy grazing pressure leads to soil compaction reducing infiltration and increasing run-off. Furthermore, reduction in biomass cover can expose soils to water and wind erosion with potentially serious consequences for soil integrity.

\section{Water footprint}

In water-scarce environments that dominate parts of SSA, water use is a key issue and the use of water by livestock needs to be considered. The bulk of water used to support livestock production is for production of feed. Livestock production accounts for $31 \%$ of agricultural water use and of this portion, $90 \%$ is used in production of feed. With increased demand for livestock products, the amount of water used for livestock production is predicted to double by 2050 (Peden et al., 2007). A key issue when considering livestock water interactions is livestock water productivity, the amount of livestock product (or financial benefit) per unit of water used in its production. Sub-Saharan Africa is a hotspot for low livestock water productivity although, as for GHG emissions, the wider benefits of livestock keeping in Africa than simply production of milk and meat are sometimes ignored. Furthermore, there are dangers in comparing livestock water productivities in industrialized systems in the Global North which rely on dedicated feed production with those in the Global South where livestock feed is often produced in areas unsuitable for arable production and where feed is often a by-product of human food production.

\section{Trade-offs associated with livestock's roles in sustainable agriculture}

Limited information is available about how far intensification can be taken without too many internal and external detrimental effects. System internal trade-offs look at how limited resources (e.g. land, labour, crop residues, cash) can be allocated across crop and livestock production (and off-farm activities), and thereby provide information on how far current systems can intensify. The crop residue for fodder $v$. for soil amendment debate has been quite intensive given the push for conservation agriculture (e.g. Giller et al., 2009; Valbuena et al., 2012). For example, work by Rusinamhodzi et al. (2013) showed that the crop residue fodder v. soil 
amendment trade-off is not strong, and that in central Zimbabwe about $25 \%$ to $50 \%$ of the crop residues can be returned to the soil without having negative effects on cattle productivity. This would be enough to ensure good soil cover, and limit soil erosion. However, despite the need for these trade-off analyses (e.g. Klapwijk et al., 2014) few other studies are available that explore these internal, resource constraint-driven, trade-offs. Externally, performance indicatordriven trade-off analyses are even less available beyond studies that show that trade-offs exist between production intensification and for example GHG emissions. Typically, in the low input systems of many low-income countries there is a large scope to improve emission intensities (i.e. the GHG emission per unit of livestock product produced) while intensifying production, but it is unclear in many systems up to what level production can be increased while still reducing emission intensity. In absolute emission terms investment in increasing the productivity of the existing cattle herd is attractive, as the animals are already there and emissions already take place. Improved feeding of these cattle will increase absolute amount of emissions (e.g. Herrero et al., 2013) but not at the same levels that it would take to achieve similar levels of improved total production through expansion of a low productivity herd. Work by Amole et al. (2017) and Rufino et al. (2009) has shown that large production increases can be achieved by relatively small changes in livestock diets. Also the low productivity of the grasslands in many agro-pastoral regions (e.g. Rufino et al., 2011) gives ample opportunity to increase livestock production (e.g. through agroforestry, incorporation of legumes or other better regulation of the access to land use to avoid overgrazing). Given the fact that demand for livestock products will rise sharply over the coming decades, this information is essential to determine where investments in livestock products can be both efficient without further major negative environmental effects.

\section{Conclusion}

This paper on the role of herbivores in sustainable agriculture in SSA has highlighted the beneficial aspects of integrating of livestock into the continent's farming systems as well as the environmental consequences. Livestock are critical to the livelihoods of rural populations in SSA and essential to address agricultural sustainability on the continent. Livestock deliver many 'goods' in smallholder farming systems in Africa including improving food and nutrition security, increased recycling of organic matter and nutrients and the associated soil fertility amendments, adding value to crop residues by turning them into nutrient-rich foods, income generation and animal traction. Therefore, the over-emphasis on the negative consequences of livestock on the environment as a result of inappropriate extrapolations based on livestock production conditions in industrialized animal production systems is rather simplistic and should be moderated by the narratives on the enormous importance of livestock in generating food security for some of the more vulnerable people in the world and other 'goods' in smallholder mixed crop and livestock systems in SSA. To enhance agricultural sustainability in SSA, the challenge is to optimize livestock's roles in the farming systems by maximizing livestock 'goods' while minimizing the 'bads'. This can be through better integration of livestock into the farming systems, efficient nutrient management systems, and provision of necessary policy and institutional support.

\section{Acknowledgements}

Some data presented in this study came from Feed the Future Innovation Lab for Sustainable Intensification project in Burkina Faso funded by United States Agency for International Development (USAID) under Cooperative Agreement No. AID-OAAL-14-00006. The contents are the sole responsibility of the authors and do not necessarily reflect the views of USAID or the United States Government.

\section{Declaration of interest}

The authors declare that they have no conflicts of interest.

\section{Ethics statement}

Not applicable.

Software and data repository resources

None of the data were deposited in an official repository.

\section{References}

Amole TA, Zijlstra M, Descheemaeker K, Ayantunde AA and Duncan AJ 2017. Assessment of lifetime performance of small ruminants under different feeding systems. Animal 11, 881-889.

Anderson S 2003. Animal genetic resources and sustainable livelihoods. Ecological Economics 45, 331-339.

Asner GP, Elmore AJ, Olander LP, Martin RE and Harris A 2004. Grazing systems, ecosystem responses, and global change. Annual Review of Environmental Resources 29, 261-299.

Baudron F, Jaleta M, Okitoi 0 and Tegegn A 2014. Conservation agriculture in African mixed crop-livestock systems: expanding the niche. Agriculture, Ecosystems and Environment 187, 171-182.

Bebe BO, Udo HMJ and Thorpe W 2002. Development of smallholder dairy systems in the Kenya highlands. Outlook on Agriculture 31, 113-120.

Diao X, Cossar F, Houssou N and Kolavalli S 2014. Mechanization in Ghana: emerging demand, and the search for alternative supply models. Food Policy 48, 168-181.

D'Odorico P, Okin GS and Bestelmeyer BT 2012. A synthetic review of feedbacks and drivers of shrub encroachment in arid grasslands. Ecohydrology 5, 520-530.

Dongmo AL, Vall E, Dugué $P$, Njoya A and Lossouarn J 2012. Designing a process of co-management of crop residues for forage and soil conservation in SudanoSahel. Journal of Sustainable Agriculture 36, 106-126.

Douxchamps S, Ayantunde A and Barron J 2014. Taking stock of forty years of agricultural water management interventions in smallholder systems of Burkina Faso. Water Resources and Rural Development 3, 1-13.

Ellis F 1998. Household strategies and rural livelihood diversification. Journal of Development Studies 35, 1-38.

Fan S and Brzeska J 2016. Sustainable food security and nutrition: demystifying conventional beliefs. Global Food Security 11, 11-16.

Food and Agriculture Organization (FAO) 2011. Mapping supply and demand for animal source food to 2030. The Food and Agriculture Organization of the United Nations, Rome, Italy. 
Garnett T, Appleby MC, Balmford A, Bateman IJ, Benton TG, Bloomer P, Burlingame B, Dawkins M, Dolan L, Fraser D, Herrero M, Hoffmann I, Smith P, Thornton PK, Toulmin C, Vermeulen SJ and Godfray HCJ 2013. Sustainable intensification in agriculture: premises and policies. Science 341, 33-34.

Gerber PJ, Steinfeld H, Henderson B, Mottet A, Opio C, Dijkman J, Falcucci A and Tempio $G$ 2013. Tackling climate change through liestock - a global assessment of emissions and mitigation opportunities. Food and Agriculture Organization of the United Nations (FAO), Rome, Italy.

Giller KE, Corbeels M, Nyamangara J, Triomphe B, Affholder F, Scopel E and Tittonell $P$ 2011. A research agenda to explore the role of conservation agriculture in African smallholder farming systems. Field Crops Research 124, 468-472.

Giller KE, Witter E, Corbeels M and Tittonell P 2009. Conservation agriculture and smallholder farming in Africa: the heretics' view. Field Crops Research 114, 23-34.

Gunton RM, Firbank LG, Inman A and Winter DM 2016. How scalable is sustainable intensification? Nature Plants 2, 1-4.

Herrero M, Havlik P, Valin H, Notenbaert A, Rufino MC, Thornton PK, Blummel $M$, Weiss F, Grace D and Obersteiner M 2013. Biomass use, production, feed efficiencies, and greenhouse gas emissions from global livestock systems. Proceedings of National Academy of Sciences 110, 20888-20893.

Hiernaux P and Ayantunde A 2004. The Fakara: a semi-arid agro-ecosystem under stress. Report of research activities of International Livestock Research Institute (ILRI) in Fakara, South-western Niger, between 1994 and 2002, Desert Margins Program, ICRISAT Niamey, Niger. https://cgspace.cgiar.org/handle/ $10568 / 1550$.

Hounkonnou D, Kossou D, Kuyper TW, Leeuwis C, Nederlof ES, Röling N, Sakyi-Dawson 0, Traoré $M$ and van Huis A 2012. An innovation systems approach to institutional change: smallholder development in West Africa. Agricultural Systems 108, 74-83.

Jones KE, Patel NG, Levy MA, Storeygard A, Balk D, Gittleman JL and Daszak P 2008. Global trends in emerging infectious diseases. Nature 451, 990-993.

Kabore TW, Houot S, Hien E, Zombré $P$, Hien V and Masse D 2010. Effect of the raw materials and mixing ratio of composted wastes on the dynamic of organic matter stabilization and nitrogen availability in composts of Sub-Saharan Africa. Bioresource Technology 101, 1002-1013.

Klapwijk C, van Wijk M, Rosenstock T, van Asten P, Thornton P and Giller K 2014. Analysis of trade-offs in agricultural systems: current status and way forward. Current Opinion in Environmental Sustainability 6, 110-115.

Mayberry D, Ash A, Prestwidge D, Godde CM, Henderson B, Duncan A, Blummel $M$, Reddy YR and Herrero M 2017. Yield gap analyses to estimate attainable bovine milk yields and evaluate options to increase production in Ethiopia and India. Agricultural Systems 155, 43-51.

Mekasha A, Gerard B, Tesfaye K, Nigatu L and Duncan AJ 2014. Inter-connection between land use/land cover change and herders'/farmers' livestock feed resource management strategies: a case study from three Ethiopian ecoenvironments. Agriculture Ecosystems and Environment 188, 150-162.

The Montpellier Panel 2013. Sustainable intensification: a new paradigm for African agriculture. A 2013 Montpellier Panel Report, Agriculture for Impact, London, UK.

National Research Council (NRC) 2010. Toward sustainable agricultural systems in the $21 \mathrm{st}$ century. Committee on Twenty-First Century Systems Agriculture; National Research Council. The National Academies Press, Washington, DC, USA.

New Partnership for Africa's Development 2003. Comprehensive Africa Agriculture Development Programme (CADDP). NEPAD, African Union, Addis Ababa, Ethiopia.

Otte MJ and Chilonda P 2002. Cattle and small ruminant production systems in sub-Saharan Africa: a systematic review. Food and Agriculture Organization of the United Nations, Rome, Italy.

Paul BK, Frelat R, Birnholz C, Ebong C, Gahigi A, Groot JCJ, Herrero M, Kagabo DM, Notenbaert A, Vanlauwe B and van Wijk MT 2018. Agricultural intensification scenarios, household food availability and greenhouse gas emissions in Rwanda: ex-ante impacts and trade-offs. Agricultural Systems 163, 16-26.

Peden D, Taddesse G and Misra AK 2007. Water and livestock for human development. In Water for food, water for life: A comprehensive assessment of water management in agriculture (ed. D Molden), pp. 485-514. Earthscan, London, UK.

Pedersen J and Benjaminsen T 2008. One leg or two? Food security and pastoralism in the Northern Sahel. Human Ecology 36, 43-57.
Pretty J, Toulmin C and Williams S 2011. Sustainable intensification in African agriculture. International Journal of Agricultural Sustainability 9, 5-24.

Reynolds LP, Wulster-Radcliffe MC, Aaron DK and Davis TA 2015. Importance of animals in agricultural sustainability and food security. The Journal of Nutrition 145, 1377-1379.

Ritzema RS, Frelat R, Douxchamps S, Silvestri S, Rufino MC, Herrero M, Giller KE, López-Ridaura S, Teufel N, Birthe P and Wijk MT 2017. Is production intensification likely to make farm households food-adequate? A simple food availability analysis across smallholder farming systems from East and West Africa. Food Security Food Security 9, 115-131.

Rockström J, Barron J and Fox P 2002. Rainwater management for increased productivity among smallholder farmers in drought prone environments. Physics and Chemistry of the Earth 27, 949-959.

Rudel TK, Kwon OJ, Paul BK, Boval M, Rao IM, Burbano D, McGroddy M, Lerner AM, White D, Cuchillo M, Luna M and Peters M 2016. Do smallholder, mixed crop-livestock livelihoods encourage sustainable agricultural practices? A metaanalysis. Land 5, 6.

Rufino MC, Dury J, Tittonell P, van Wijk MT, Herrero M, Zingore S, Mapfumo P and Giller KE 2011. Competing use of organic resources, village-level interactions between farm types and climate variability in a communal area of NE Zimbabwe. Agricultural Systems 104, 175-190.

Rufino MC, Herrero M, van Wijk MT, Hemerik L, De Ridder N and Giller KE 2009. Lifetime productivity of dairy cows in smallholder farming systems of the central highlands of Kenya. Animal Biology 3, 1044-1056.

Rusinamhodzi L, Corbeels M, Zingore S, Nyamangara J and Giller KE 2013. Pushing the envelope? Maize production intensification and the role of cattle manure in recovery of degraded soils in smallholder farming areas of Zimbabwe. Field Crops Research 147, 40-53.

Savadogo K, Reardon T and Pietola K 1998. Adoption of improved land use technologies to increase food security in Burkina Faso: relating animal traction, productivity, and non-farm income. Agricultural Systems 58, 441-464.

Schiere JB, Ibrahim MNM and van Keulen H 2002. The role of livestock for sustainability in mixed farming: criteria and scenario studies under varying resource allocation. Agriculture, Ecosystems and Environment 90, 139-153.

Sheahan M and Barrett CB 2017. Ten striking facts about agricultural input use in Sub-Saharan Africa. Food Policy 67, 12-25.

Smith A, Snapp S, Chikowo R, Thorne P, Bekunda M and Glover J 2017. Measuring sustainable intensification in smallholder agroecosystems: a review. Global Food Security 12, 127-138.

Steinfeld H, Gerber P, Wassenaar T, Castel V, Rosales M and Haan CD 2006. Livestock's long shadow: environmental issues and options. Food and Agriculture Organization of the United Nations, Rome, Italy.

Udo HMJ, Aklilu HA, Phong LT, Bosma RH, Budisatria IGS, Patil BR, Samdup T and Bebe BO 2011. Impact of intensification of different types of livestock production in smallholder crop-livestock systems. Livestock Science 139, 22-29.

Valbuena D, Erenstein O, Homann-Kee Tui S, Abdoulaye T, Claessens L, Duncan AJ, Gérard B, Rufino MC, Teufel N, van Rooyen A and van Wijk MT 2012. Conservation Agriculture in mixed crop-livestock systems: scoping crop residue trade-offs in Sub-Saharan Africa and South Asia. Field Crops Research 132, 175-184.

Vall E, Marre-Cast L and Kamgang HJ 2017. Chemins d'intensification et durabilité des exploitations de polyculture-élevage en Afrique subsaharienne: contribution de I'association agriculture-élevage. Cahier d'Agriculture 26, 25006.

Weiler V, Udo HMJ, Viets T, Crane TA and de Boer IJM 2014. Handling multi-functionality of livestock in a life cycle assessment: the case of smallholder dairying in Kenya. Current Opinion in Environmental Sustainability 8, 29-38.

Wilkinson JM 2011. Re-defining efficiency of feed use by livestock. Animal 5, 1014-1022.

Zougmoré R, Partey $S$, Ouédraogo $M$, Omitoyin $B$, Thomas $T$, Ayantunde $A$, Ericksen P, Said M and Jalloh A 2016. Toward climate-smart agriculture in West Africa: a review of climate change impacts, adaptation strategies and policy developments for the livestock, fishery and crop production sectors. Agriculture and Food Security 5, 26. 